\title{
Pengaruh Tanggung Jawab Perusahaan dalam Menanggulangi Krisis terhadap Reputasi Perusahaan
}

\author{
Theresia Diyah Wulandari \\ Universitas Atma Jaya Yogyakarta \\ Jl. Babarsari No. 6, Yogyakarta 55281 \\ Email: wulandaricupriantoro@yahoo.com.au
}

\begin{abstract}
It must be admitted that reputation is an important part of company to run its business. Regarding the fact that reputation is very fragile in responding the influence of crisis, it is necessary to chose appropriate strategy in maintaining the reputation. Based on this regard, the research aims to examine the extent to which company's effort to overcome crisis influences the maintanence of its reputation. The appropriate communication theory from which this research is started, is Coombs and Holladay's Situational Crisis Theory. SCT theory exemplifies a number of strategic effort of company's which will be effective to overcome crisis. In this sense, it may be not too exaggerated to mention that the theory provide a usefull guideline for managers to overcome crises which potentially influence reputation. Furthermore, the research employs survey method to gather data from respondents. The result of the research shows that kind of responsibility chosen by company as its effort to overcome the crises would significantly influence the reputation.
\end{abstract}

Key words: corporate, responsibility, communication, reputation

\begin{abstract}
Abstrak: Latar belakang penelitian ini adalah reputasi penting bagi perusahaan dalam menjalankan bisnisnya. Reputasi perusahaan dapat rusak akibat sesuatu yang tidak terduga yang disebut krisis. Reputasi perusahaan harus dilindungi dari berbagai ancaman, dan untuk mengatasinya manajer krisis perlu memilih strategi respon proteksi terhadap reputasi. Tujuan dalam penelitian ini adalah menemukan korelasi antara bentuk-bentuk tanggungjawab krisis perusahaan bagi pemulihan reputasi. Desain dari penelitian ini berasal teori komunikasi krisis situasional Coombs dan Holladay's yang menjadi panduan bagi manajer krisis memahami strategi respon krisis. Teori ini menyimpulkan bentuk-bentuk tanggungjawab krisis dan reputasi perusahaan merupakan variabel penentu. Analisa penelitian menggunakan metode survei responden yang berisi tiga stimulus kejadian krisis. Tujuan dari penelitian ini menyatakan bahwa pilihan tanggungjawab perusahaan memiliki pengaruh yang signifikan terhadap reputasi.
\end{abstract}

Kata kunci: perusahaan, tanggungjawab, komunikasi, reputasi

Reputasi dibutuhkan perusahaan dalam menjalankan bisnisnya. Dengan reputasi yang baik, bisnis juga dapat dijalankan perusahaan dengan baik karena citra dan kepercayaan para pemangku kepentingan dibangun dari reputasi yang baik. Winkleman (1999) menyebutkan bahwa reputasi perusahaan adalah sesuatu hal yang diakui sangat bernilai karena mempengaruhi citra perusahaan di mata pihak lain.

Reputasi sangat dipengaruhi oleh sesuatu yang terjadi di perusahaan. Oleh karena itu saat hal-hal positif terjadi di perusahaan maka reputasi perusahaan akan baik. Sebaliknya, kejadian yang buruk 
Jurnal

akan membuat reputasi perusahaan juga menjadi buruk. Salah satu kejadian buruk yang menimpa perusahaan disebut krisis yang datang tanpa terencana dan tidak diduga oleh pihak perusahaan dan berdampak pada jalannya bisnis perusahaan. Ini karena dampak dari krisis dipercaya berpengaruh hingga ke level pemangku kepentingan atau stakeholders perusahaan (Barton, 2001; Dowling, 2002).

Dampak buruk dari krisis dapat diatasi pihak perusahaan agar reputasi tidak menjadi lebih buruk bagi perusahaan dengan menggunakan strategi penanggulangan krisis yang tepat. Cara yang paling tepat adalah dengan menggunakan strategi komunikasi yang baik. Strategi komunikasi harus dikemas secara baik dengan tujuan untuk melindungi reputasi perusahaan karena krisis dapat diatasi jika perusahaan mampu merumuskan strategi komunikasi yang baik. Begitu juga sebaliknya, strategi komunikasi yang buruk dapat memperparah krisis itu sendiri (Coombs dan Holladay, 2005).

Menurut Winkleman (1999) reputasi perusahaan dapat dikenali sumber permasalahannya. Dengan mengenali sumber permasalahannya, pihak yang bertanggungjawab menanggulangi krisis dapat melihat bagaimana reaksi para stakeholders atau pemangku kepentingan yang berpengaruh pada strategi komunikasi penanggulangan krisis (Ahluwalia, 2000; Dawar dan Pillutla, 2000; Dean, 2004). Salah satunya adalah pendekatan situasional untuk menentukan strategi komunikasi efektif sebagai bagian dari upaya respon terhadap krisis yang akan dijadikan pegangan perusahaan. Tujuannya tentu agar pasca krisis, reputasi perusahaan dapat tetap terlindungi.

Benson (1988) adalah pioneer teori tentang strategi komunikasi penanggulangan krisis dengan menggunakan pendekatan situasional dalam krisis. Teori berkembang sampai dengan temuan teori komunikasi situasional terbaru disampaikan oleh Coombs yang disebut dengan istilah Situasional Crisis Communication Theory (SCCT) atau Teori Komunikasi Krisis Situasional (1999). Penelitian ini merupakan lanjutan dari penelitian Benson sebelumnya di mana strategi respon krisis dengan situasi krisis digabungkan dengan konsep pilihan manajemen krisis.

Dari uraian yang dibahas di atas, pertanyaan dari penelitian ini adalah bagaimana pengaruh kemampuan perusahaan memilih pertanggungjawaban respon krisis perusahaan terhadap upaya pemulihan reputasi perusahaan. Hal ini berkaitan dengan tujuan dari penelitian untuk menganalisa pengaruh kemampuan perusahaan memilih pertanggungjawaban respon krisis perusahaan terhadap upaya pemulihan reputasi perusahaan.

Reputasi secara luas dihubungkan dengan nilai dan identitas aset. Aset yang memiliki reputasi yang baik dapat menarik minat konsumen, menarik minat berinvestasi para investor, meningkatkan kinerja keuangan perusahaan, menarik minat kerja para karyawan level top management, 
Jurnal

ILMU KOMUNIKASI

meningkatkan tingkat pengembalian nilai aset, meningkatkan kompetisi produk, dan mendapatkan penilaian dan analisa positif dari kalangan analis bursa (Carmeli dan Tishler, 2005; Davies et al., 2003; Fombrun dan Gardberg, 2000; Fombrun dan van Riel, 2004). Reputasi merupakan bagian dari evaluasi para pemangku kepentingan untuk melihat bagaimana organisasi atau perusahaan menunjukkan performa yang diharapkan publik berdasarkan pengalaman-pengalaman yang telah dilakukan sebelumnya (Wartick, 1992). Sebagai bagian dari evaluasi, reputasi dikaitkan dengan sesuatu yang sifatnya disukai atau tidak disukai, dan peranan stakeholder dalam kelompoknya masing-masing dapat mempengaruhi dan dipengaruhi oleh perilaku perusahaan (Agle et al., 1999; Bryson, 2004) karena reputasi terbangun dari informasi perusahaan yang didapatkan dari kalangan para pemangku kepentingan (Fombrun dan van Riel, 2004).

Dalam penelitian Coombs dan Holladays (2002), ada beberapa dasar pertimbangan lain selain reputasi selama terjadinya krisis terutama menyangkut keamanan publik. Peneliti lain membuktikan suatu temuan bahwa publik selalu ingin tahu dan memahami pilihan apa yang akan dilakukan pihak perusahaan saat krisis, terutama dalam menentukan tujuan akhir reputasi (Coombs, 1999a; Coombs \& Holladays, 2001; Struges, 1994). Namun inti dari fokus SCCT adalah bagaimana mengatur reputasi saat terjadinya krisis. Dari sini muncul satu temuan jika reputasi perusahaan sangat dipengaruhi oleh bentuk-bentuk pilihan pertanggungjawaban respon krisis (Coombs dan Holladays, 2002).

Strategi komunikasi yang paling tepat sebagai bagian dari respon krisis dicari para pelaku public relations yang bertanggungjawab mengembalikan reputasi pasca krisis. Hal yang sama juga disampaikan oleh Fomburn (1996) yang mengatakan bahwa dengan bentuk-bentuk strategi penanggulangan krisis yang tepat, perusahaan akan semakin sedikit merasakan risiko dari pengaruh negatif krisis itu. Selain itu pilihan strategi yang tepat juga akan membuat perusahaan sedikit kehilangan uang mereka.

Menurut Benson (1988), salah satu cara merumuskan strategi komunikasi penanggulangan krisis yang tepat adalah dengan menggunakan pendekatan situasional krisis. Hal ini didasarkan pada beberapa penelitian sebelumnya yang menunjukkan fakta temuan bahwa satu kejadian krisis mempengaruhi efektivitas respon terhadap krisis (e.g., Benoit, 1995; Coombs, 1999b; Hearit, 1996). Namun teori selanjutnya mengarah pada pemahaman bahwa untuk dapat merumuskan strategi komunikasi yang tepat menanggulangi kondisi krisis, pelaku public relations harus memahami terlebih dahulu tipe-tipe krisis (Coombs dan Holladays, 2001). Salah satu teori yang merumuskan tentang tipe- 
Jurnal

tipe krisis adalah teori Situasional Crisis Communication Theory (SCCT) atau teori komunikasi tentang krisis situasional.

Strategi respon krisis seharusnya dapat meredakan kerusakan reputasi dengan cara menunjukkan perhatian perusahaan kepada korban dan perusahaan tahu bagaimana mengambil sikap yang tepat dan sesuai dengan harapan publik. Dalam rangka mendukung upaya ini Coombs dan Holladay (1996) menemukan strategi respon yang dapat meredakan kerusakan reputasi dalam kasus perusahaan yang berperilaku buruk. Teori SCCT memiliki kerangka yang tepat dijadikan sebagai arahan bagaimana mengupayakan perlindungan reputasi dengan menggunakan prinsip komunikasi pasca krisis.

SCCT dapat digunakan sebagai panduan penelitian tentang strategi komunikasi penanggulangan krisis, terutama dalam menganalisa metode eksperimental atau studi kasus. Teori krisis situasional mengidentifikasi bagaimana hubungan krisis dan reputasi dapat dipengaruhi oleh respon dari pemangku kepentingan, dapat dipahami pula bagaimana publik akan merespon upaya penanggulangan krisis itu pasca krisis.

Menurut teori ini kejadian krisis terbagi dalam tiga tipe utama, yaitu kejadian krisis yang meninggalkan masalah, kejadian krisis yang tidak meninggalkan masalah, dan kejadian krisis akibat kesalahan eksternal. Ketiga tipe inilah yang disinyalir memberi dampak pada reputasi perusahaan.

Setelah menemukan tipe krisis yang menimpa perusahaan, pelaku public relations harus mampu menentukan level tanggungjawab krisis sebagai bagian dari strategi komunikasi respon krisis yang dipilih. Fokus utama pada teori dan model yang dikemukakan oleh Coombs dan Holladays itu berkaitan dengan kemampuan seseorang atau perusahaan memilih tanggungjawab krisis yang dapat diemban pihak perusahaan. Ini diperkuat dengan adanya pendapat bahwa persepsi atas tanggungjawab terhadap krisis memiliki keterkaitan sangat kuat bagi seseorang atau perusahaan dalam menghadapi suatu kejadian yang nantinya akan berdampak pada reputasi.

Penelitian ini menggunakan dua variabel penelitian, yaitu sikap dan tanggungjawab perusahaan atau perusahaan dalam merumuskan strategi respon krisis (TO) dan reputasi perusahaan (RO). Penentuan dua variabel dalam penelitian ini seperti disampaikan oleh Commbs (1998) yang mengatakan bahwa reputasi perusahaan berhubungan erat dengan kemampuan perusahaan memilih tanggungjawab krisis yang diambil pihak perusahaan sebagai salah satu upaya perusahaan mencari akar persoalan dari kejadian krisis yang dihadapi.

Tanggungjawab perusahaan mengacu pada situasi krisis di mana perusahaan menjadi pihak yang paling bertanggungjawab atau justru tanggungjawab seharusnya dipikul oleh pihak lain, bukan 
Jurnal

ILMU KOMUNIKASI

tanggungjawab perusahaan. Reputasi perusahaan adalah citra perusahaan di mata pihak lain saat pihak perusahaan mengalami kejadian krisis, untuk dinilai apakah reputasi mereka dinilai tetap baik atau justru menjadi buruk di mata publik pasca mengalami satu kejadian krisis. Uraian tersebut dapat dituangkan ke dalam bagan kerangka pemikiran sebagai berikut.

\section{Skema 1. Kerangka Pemikiran}

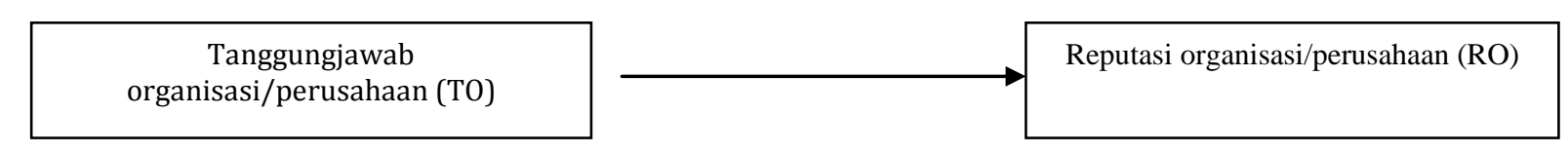

\section{METODOLOGI PENELITIAN}

Penelitian ini merupakan penelitian survei, yaitu penelitian yang mengambil sampel dari satu populasi dengan menggunakan kuesioner untuk mengukur variabel penelitian yang ditujukan untuk menganalisis hubungan yang ada antara kendali organsiasi, tanggungjawab organisasi, dan reputasi organisasi.

Metode penelitian ini menggunakan metode survei yang digunakan melalui pembagian kuesioner kepada 50 reseponden di level eksekutif manajemen Public Relation perusahaan sektor riil dan jasa di Jakarta. Masing-masing responden menerima 8 pernyataan kuesioner yang mewakili dua variabel, yaitu variabel tanggungjawab organisasi dan reputasi organisasi. Ke-8 pernyataan itu diulang pada tiga stimulan kejadian krisis berdasarkan tipe krisis, yaitu kejadian krisis yang meninggalkan masalah, kejadian krisis yang tidak meninggalkan masalah, dan kejadian krisis akibat faktor eksternal.

Populasi penelitian ini adalah para pemangku tanggungjawab eksekutif manajemen public relations perusahaan-perusahaan sektor riil dan jasa di Jakarta dengan fokus kerja sebagai pihak yang bertangung jawab menanggulangi masalah krisis di perusahaan. Metode penarikan sampel yang digunakan adalah metode pertimbangan atau purposive sampling, yaitu merupakan salah satu dari teknik non-probabilita sampling di mana penarikan sampel non-probabilitas ini berdasarkan pada kriteria-kriteria tertentu (Hermawan, 2003:56). Menurut Ferdinand (2002), penggunaan jumlah sampel untuk pengujian model yang baik antara 100 hingga 200 atau tergantung pada jumlah variabel penelitian yang digunakan, yaitu jumlah variabel dikali 5 sampai 10. Penelitian ini menggunakan dua variabel. Berdasarkan teori tentang penggunaan jumlah sampel untuk pengujian model, jumlah 
Jurnal

ILMU KOMUNIKASI

responden dalam penelitian ini adalah 50 responden. Dengan demikian penentuan jumlah sampel dalam penelitian dianggap sudah memenuhi syarat.

Dalam penelitian ini variabel bebas adalah tanggungjawab organisasi sedangkan reputasi organisasi merupakan varibel terikat yang diukur dengan menggunakan metode regresi sederhana. Tanggungjawab organisiasi adalah kemampuan perusahaan memilih strategi respon pada satu kejadian krisis sehingga krisis dapat ditanggulangi. Variabel ini diukur dengan menggunakan pengukuran yang telah digunakan Griffin, Babin, dan Darden (1992), berkaitan dengan tiga item tentang kesalahan. Pertanyaan kepada responden ini adalah: 1). Dalam kondisi apapun, krisis bukan hanya tanggungjawab perusahaan namun ada pihak lain yang harus bertanggungjawab pada kejadian krisis; 2). Kesalahan atas kejadian krisis merupakan tanggungjawab perusahaan; dan 3). Kesalahan atas kejadian krisis bukan merupakan tanggungjawab perusahaan.

Variabel reputasi organisasi diukur dengan lima item mengenai skala reputasi perusahaan yang diadaptasi oleh Coombs dan Holladays (1996) dari skala pengukuran karakter milik McCroskey (1996) tentang skala pengukuran etos (McCroskey’s Ethos Scale). Lima item yang digunakan pada penelitian ini, yaitu: 1). Perusahaan peduli dengan kesejahteraan para pemangku kepentingan; 2). Perusahaan pada dasarnya tidak jujur; 3). Saya tidak percaya dengan apa yang disampaikan pihak perusahaan; 4). Saya percaya dengan apa yang disampaikan pihak perusahaan; dan 5). Perusahaan tidak memperhatikan kesejahteraan para pemangku kepentingan.

Kedua variabel tersebut dibuat dalam bentuk observed variabel di mana seluruh pernyataan dalam bentuk skala Likert hasil dari masing-masing kontruk variabel dibobotkan (dijumlahkan), dibagi berdasarkan masing-masing studi kasus kejadian krisis perusahaan. Masing-masing variabel akan diuji dengan menggunakan tiga kasus yang digambarkan sebagai suatu kejadian krisis perusahaan berdasarkan tiga kategori kejadian krisis.

Kasus pertama berdasarkan kategori penyebab kejadian krisis yang tidak meninggalkan masalah. Penulis memilih kejadian krisis yang tidak meninggalkan masalah pada PT Nutrifood melalui isu adanya kandungan aspartam. Hal ini didasarkan pada fakta dan wawancara pada pihak manajemen perusahaan bahwa perusahaan ini mengalami kejadian krisis akibat isu aspartam dalam setiap produk diet Nutrifood namun akhirnya isu tersebut dapat diatasi dan tidak meninggalkan masalah lebih lanjut.

Kasus kedua adalah kejadian krisis yang masih meninggalkan masalah, dan penulis mengambil kejadian krisis yang menimpa RS Omni International. Berdasarkan fakta dan wawancara pihak manajemen, pihak rumah sakit mengalami krisis sejak adanya klaim kasus malpraktek pasien Prita 
Jurnal

Mulyasari. Dengan strategi penanggulangan krisis yang dipilih perusahaan, kejadian kasus krisis itu tidak selesai, bahkan meninggalkan masalah lanjutan dengan adanya klaim dari pasien lain yang mengaku mengalami kejadian malpraktek serupa dengan yang dialami Prita Mulyasari.

Kasus ketiga adalah kejadian krisis akibat adanya faktor eksternal atau regulasi, yaitu kejadian krisis PT Lapindo yang mengalami kejadian krisis lumpur Lapindo di Sidoarjo. Berdasarkan fenomena yang diamati, perusahaan ini mengaku kejadian meluapnya lumpur di Sidoarjo karena adanya kesalahan di luar kemampuan perusahaan akibat adanya unsur campur tangan alam (forced major).

Berdasarkan uji validitas dan reliabilitas pada kuesioner, ditemukan pengujian validitas untuk responden staf divisi humas perusahaan dengan seluruh indikator variabel tanggungjawab organisasi dan reputasi organisasi adalah valid karena nilai sign-1 tailed-nya kurang dari $\alpha 0,05$ dan $\alpha 0,1$. Korelasi antara masing-masing indikator terhadap skor total juga memiliki korelasi kuat yang diperlihatkan dengan nilai Pearson correlations (r-hitung) dari keseluruhan korelasi indikator variabel hampir mendekati 1, yaitu dengan nilai berkisar 0,048 hingga 0,820.

Berdasarkan uji reliabilitas dengan menggunakan metode Cronbach’s Alpha dengan bantuan software SPSS versi 15.0 ditemukan bahwa untuk uji reliabilitas responden pada kejadian yang menimbulkan masalah diperoleh dari masing-masing konstruk antara lain pada 3 pertanyaan untuk tanggungjawab organisasi memiliki Cronbach’s Alpha sebesar 0,941 dan konstruk reputasi organisasi memiliki Croncach’s Alpha sebesar 0,928.

Uji reliabilitas untuk kasus kejadian yang tidak menimbulkan masalah, diperoleh dari masingmasing konstruk antara lain konstruk tanggungjawab organisasi pada 3 pertanyaan memiliki Cronbach’s Alpha sebesar 0,911, dan untuk konstruk reputasi organisasi memiliki Croncach’s Alpha sebesar 0,969. Untuk kejadian akibat faktor eksternal, diperoleh dari masing-masing konstruk tanggungjawab organisasi pada 3 pertanyaan memiliki Cronbach’s Alpha sebesar 0,951, dan untuk konstruk reputasi organisasi memiliki Croncach’s Alpha sebesar 0,950.

\section{HASIL PENELITIAN}

Pada penelitian ini jumlah kuesioner yang disebar pada responden pimpinan divisi humas perusahaan adalah sebanyak 50 kuesioner, dan semuanya kembali. Karakteristik demografik dari 50 responden terlihat bahwa mereka yang bekerja pada sektor jasa mencapai 30 persen atau 15 orang, 
Jurnal

begitu juga pada sektor otomotif mencapai 30 persen atau 15 orang, dilanjutkan kemudian sektor pendidikan 10 persen atau 5 orang, manufaktur 10 persen atau 5 orang, selanjutnya elektronik, kesehatan, keuangan, food and beverage, keuangan, dan perbankan masing-masing 10 persen atau 10 orang.

Dilihat dari jenis kelamin, jumlah responden staf eksekutif humas perusahaan yang diteliti adalah laki-laki berjumlah 23 orang atau 46 persen dan responden perempuan sebesar 27 orang atau 54 persen, dan berdasarkan pendidikan responden, mereka yang memiliki pendidikan terakhir diploma (D3) sebesar 5 orang atau 10 persen, dilanjutkan kemudian dengan responden yang memiliki pendidikan terakhir sarjana (S1) mencapai 34 orang atau 68 persen dan pendidikan terakhir master (S2) sebesar 11 orang atau 22 persen.

Umumnya staf eksekutif divisi humas perusahaan yang diteliti memiliki masa kerja sepanjang karirnya sebagai staf divisi humas lebih dari 10 tahun sebesar 10 orang atau 20 persen, dan responden yang memiliki masa kerja 5-10 tahun mencapai 34 orang atau 68 persen, dan yang bekerja kurang dari 5 tahun mencapai 6 orang atau 12 persen.

Setelah kuesioner selesai disebarkan dan dikumpulkan, data dari kuesioner tersebut diolah untuk mengetahui nilai mean atau nilai rata-rata dan penyimpangannya. Berdasarkan perhitungan, nilai ratarata nilai mean untuk dimensi Tanggungjawab Organisasi (TO) pada kasus yang meninggalkan masalah, jawaban responden staf eksekutif divisi humas perusahaan memiliki rata-rata nilai mean sebesar 2.79 yang artinya mendekati jawaban tidak setuju dengan penyimpangan (standar deviasi) jawaban responden staf eksekutif divisi humas perusahaan terhadap rata-rata sangat tidak setuju sebesar 1.278. Sedangkan pendapat responden staf eksekutif divisi humas perusahaan pada variabel reputasi organisasi (RO) pada kasus yang meninggalkan masalah memiliki rata-rata jawaban responden adalah ragu-ragu dengan nilai mean adalah 3.05, dan standar deviasinya 1.155 sangat tidak setuju.

Berdasarkan perhitungan terlihat bahwa nilai rata-rata nilai mean untuk dimensi Tanggungjawab Organisasi (TO) pada kasus yang tidak meninggalkan masalah, jawaban responden staf eksekutif divisi humas perusahaan memiliki rata-rata nilai mean adalah 3.79 yang artinya mendekati jawaban tidak setuju dengan penyimpangan (standar deviasi) jawaban responden staf eksekutif divisi humas perusahaan terhadap rata-rata sangat tidak setuju sebesar 1.278. Sedangkan pendapat responden staf eksekutif divisi humas perusahaan pada variabel reputasi organisasi (RO) pada kasus yang tidak meninggalkan masalah memiliki rata-rata jawaban responden adalah ragu-ragu dengan nilai mean adalah 3.35, dan standar deviasinya 1.155 sangat tidak setuju. 
Jurnal

Berdasarkan perhitungan terlihat bahwa nilai rata-rata nilai mean untuk dimensi Tanggungjawab Organisasi (TO) pada kasus akibat faktor eksternal, jawaban responden staf eksekutif divisi humas perusahaan memiliki rata-rata nilai mean adalah 3.79 yang artinya mendekati jawaban tidak setuju dengan penyimpangan (standar deviasi) jawaban responden staf eksekutif divisi humas perusahaan terhadap rata-rata sangat tidak setuju sebesar 1.278.

Pendapat responden staf eksekutif divisi humas perusahaan pada variabel reputasi organisasi (RO) pada kasus akibat faktor eksternal memiliki rata-rata jawaban responden adalah ragu-ragu dengan nilai mean adalah 3.45, dan standar deviasinya 1.155 sangat tidak setuju.

Setelah dilakukan uji validitas, reliabilitas, dan pemahaman akan statistik deskriptif pada masingmasing variabel penelitian, maka uji selanjutnya adalah pengujian hipotesis melalui uji regresi sederhana pada kedua variabel penelitian untuk mengetahui pengaruh dari variabel independen terhadap variabel dependen dengan bantuan software SPSS versi 15.00.

Pengukuran pengaruh dari variabel-variabel penelitian menggunakan angka pembanding sign-1 tailed terhadap $\alpha$ 0.05. Jika sign-1 tailed > 0.05 maka H0 diterima, H1 ditolak, dan jika sign-1 tailed < 0.05 H0 ditolak, H1 diterima. Tabel 1. berikut ini menunjukkan hasil regresi sederhana pada masingmasing kejadian krisis perusahaan.

Tabel 1. Hasil Analisa Regresi Sederhana

\begin{tabular}{lccc}
\hline & \multicolumn{3}{c}{ Variabel bebas: Tanggung jawab Organisasi } \\
\hline Variabel Terikat & $\begin{array}{c}\text { Kejadian yang } \\
\text { Meninggalkan Masalah }\end{array}$ & $\begin{array}{c}\text { Kejadian yang Tidak } \\
\text { Meninggalkan Masalah }\end{array}$ & $\begin{array}{c}\text { Kejadian Akibat Faktor } \\
\text { Eksternal }\end{array}$ \\
\hline Reputasi Organisasi & 0.287 & 0.003 & 0.003 \\
\hline Sumber: Data diolah & & &
\end{tabular}

Tabel 1 menunjukkan pada kondisi kejadian krisis yang meninggalkan masalah, hipotesis nol (H0) berbunyi “tidak ada pengaruh tanggungjawab organisasi terhadap reputasi organisasi”, sedangkan hipotesis alternatif (H1) berbunyi "ada pengaruh tanggungjawab organisasi terhadap reputasi organisasi”. Angka signifikansi hasil perhitungan diperoleh sebesar 0,287. Mengacu pada keputusan menggunakan kriteria jika angka signifikasi riset < 0.05, maka H0 ditolak dan jika angka signifikansi hasil riset $>0.05$, maka H0 diterima. Didasarkan pada ketentuan di atas maka signifikansi hitung 0.287 $>$ 0.05, maka H0 ditolak dan H1 diterima. Artinya, tidak ada pengaruh tanggungjawab organisasi terhadap reputasi organisasi. Jika dilihat dari kontribusi variabel pilihan tanggungjawab organisasi pada kejadian krisis yang meninggalkan masalah hanya mampu mempengaruhi reputasi perusahaan sebesar 5,2\% dan 94,8\% sisanya dipengaruhi oleh faktor-faktor lain. 
Jurnal

ILMU KOMUNIKASI

Pada kondisi kejadian krisis yang tidak meninggalkan masalah, hipotesis nol (H0) berbunyi “tidak ada pengaruh tanggungjawab organisasi terhadap reputasi organisasi”, sedangkan hipotesis alternatif (H1) berbunyi “ada pengaruh tanggungjawab organisasi terhadap reputasi organisasi”. Angka signifikansi hasil perhitungan diperoleh sebesar 0.003. Mengacu pada keputusan menggunakan kriteria jika angka signifikasi riset < 0.05, maka H0 ditolak dan jika angka signifikansi hasil riset >0.05, maka H0 diterima. Didasarkan pada ketentuan di atas maka signifikansi riset 0.003<0.005, maka H0 ditolak dan $\mathrm{H} 1$ diterima. Artinya ada pengaruh tanggungjawab organisasi terhadap reputasi organisasi pada kejadian krisis yang tidak meninggalkan masalah.

Pada kondisi kejadian krisis akibat faktor eksternal dengan hipotesis nol (H0) berbunyi "tidak ada pengaruh tanggungjawab organisasi terhadap reputasi organisasi”, sedangkan hipotesis alternatif (H1) berbunyi “ada pengaruh tanggungjawab organisasi terhadap reputasi organisasi”. Angka signifikansi hasil perhitungan diperoleh sebesar 0.003. Mengacu pada keputusan menggunakan kriteria jika angka signifikasi riset < 0.05, maka H0 ditolak dan jika angka signifikansi hasil riset >0.05, maka H0 diterima. Didasarkan pada ketentuan di atas maka signifikansi hitung 0.003<0.005, maka H0 ditolak dan H1 diterima. Artinya pada kejadian krisis akibat faktor eksternal, ada pengaruh tanggungjawab organisasi terhadap reputasi organisasi.

Kontribusi variabel tanggungjawab organisasi pada kejadian krisis yang tidak meninggalkan masalah, mempengaruhi reputasi perusahaan sebesar 21,4\% dan 78,6\% sisanya dipengaruhi oleh faktor lain. Untuk kejadian krisis akibat faktor eksternal, variable pilihan tanggungjawab organisasi mempengaruhi reputasi perusahaan sebesar 22\%, dan 78\% sisanya dipengaruhi faktor lain yang belum teridentifikasi.

\section{PEMBAHASAN}

Berdasarkan hasil analisis regresi, diketahui nilai sig pada kejadian krisis yang meninggalkan masalah sebesar 0,287 (>0,05), maka disimpulkan bahwa pilihan tanggungjawab organisasi tidak mempengaruhi reputasi perusahaan. Untuk kejadian krisis yang meninggalkan masalah dan akibat faktor eksternal diketahui memiliki nilai sig sebesar 0,003 $(<0,005)$, maka disimpulkan bahwa pilihan tanggungjawab krisis mempengaruhi reputasi perusahaan.

Hasil penghitungan ini memperkuat teori komunikasi krisis situasional William Timothy Coombs dan Sherry J. Holladay yang mengatakan bahwa strategi penanggulangan krisis dapat meredakan 
Jurnal

ILMU KOMUNIKASI

kerusakan reputasi. Teori ini mengidentifikasi bagaimana reputasi dapat dipengaruhi oleh upaya perusahaan melakukan respon penanggulangan krisis pasca kejadian. Strategi penanggulangan krisis melalui pilihan tanggungjawab yang diharapkan mampu meredam reputasi pasca krisis karena inti dari fokus SCCT ini adalah bagaimana mengatur reputasi saat terjadinya krisis. Dari sini muncul satu temuan jika reputasi perusahaan sangat dipengaruhi oleh bentuk-bentuk pilihan pertanggungjawaban respon krisis (Coombs dan Holladays, 2002).

Selain itu variabel reputasi perusahaan yang diadaptasi dari skala pengukuran McCroskey juga membuktikan bahwa pengukuran reputasi ada pada pendapat bahwa perusahaan peduli, perusahaan jujur, dan perusahaan bisa dipercaya. Demikian juga untuk variabel pilihan tanggungjawab yang diukur melalui pendapat bahwa perusahaan mau bertanggungjawab atas kejadian krisis.

Oleh karena itu dapat dikatakan bahwa pada perusahaan yang memiliki kejadian krisis yang menimbulkan masalah kembali, dipastikan pemulihan reputasinya akan sulit karena pilihan tanggungjawabnya kurang tepat (5,2\%). Sebaliknya, untuk perusahaan yang memiliki kejadian krisis yang tidak menimbulkan masalah dapat memulihkan reputasi perusahaan karena pilihan tanggungjawabnya lebih baik jika dibandingkan dengan perusahaan dengan kejadian krisis berkelanjutan (21,4\%). Demikian juga untuk kejadian krisis akibat faktor eksternal, reputasi perusahaan dapat kembali pulih karena pilihan tanggungjawab krisis yang lebih baik (22\%).

\section{KESIMPULAN}

Penelitian ini menggunakan sampel sebanyak 50 eksekutif public relations pada perusahaan beberapa sektor industri bertujuan untuk menguji hipotesis bahwa tanggungjawab organsiasi berpengaruh terhadap reputasi perusahaan.

Hipotesis tersebut telah diuji dengan menggunakan tiga stimulan tipe kejadian krisis, mulai dari kejadian krisis yang meninggalkan masalah, kejadian krisis yang tidak meninggalkan masalah, dan kejadian krisis akibat faktor eksternal. Berkaitan dengan tipe kejadian krisis yang meninggalkan masalah, maka hasil penelitian menunjukkan bahwa: 1) Pada kejadian krisis yang masih meninggalkan masalah, tidak ada pengaruh tanggungjawab organisasi terhadap reputasi organisasi (sig 0.287>0.05); 2). Pada kejadian krisis yang tidak meninggalkan masalah, ada pengaruh tanggungjawab organisasi terhadap reputasi organisasi (sig 0.003>0.05) dan 3) Pada kejadian krisis akibat faktor eksternal, ada pengaruh tanggungjawab organisasi terhadap reputasi organisasi (sig 0.003>0.05). 
Jurnal

Berkaitan dengan tipe kejadian krisis, maka hasil penelitian menunjukkan bahwa: 1) Perusahaan yang mengalami krisis yang berkelanjutan tidak memiliki kemampuan yang baik dalam memilih tanggungjawab krisis yang berpengaruh pada reputasi; 2) Perusahaan yang tidak mengalami krisis berkelanjutan memiliki kemampuan yang baik dalam memilih tanggungjawab krisis sebagai upaya pemulihan reputasi; dan 3) Pada perusahaan yang mengalami kejadian akibat faktor eksternal cenderung memiliki pilihan tanggungjawab krisis yang sudah baik sebagai upaya memperbaiki reputasi.

Penelitian ini memiliki sejumlah keterbatasan karena baru dilakukan pada responden yang merupakan staf eksekutif humas beberapa perusahaan sektor tertentu, sehingga tidak bisa di generalisir pada semua humas perusahaan. Selain itu, penelitian ini juga tidak membahas faktor-faktor yang turut mendukung terjadinya reputasi suatu lembaga, misalnya tanggung jawab sosial perusahaan, lingkungan, kedekatan dengan media, dan dukungan investor.

Oleh karena itu, untuk penelitian selanjutnya dapat dilakukan dengan sampel yang lebih lengkap dan mencakup karakter responden yang lebih banyak, lintas sektor, tidak terbatas pada responden di beberapa sektor industri saja.

\section{DAFTAR PUSTAKA}

Barton, L., (2001). Crisis in Organization II ( $2^{\text {nd }}$ ed.). Cincinnati, OH: College Division South-Western.

Benoit, W. L., (1995). Account, Excuses, and Aplogie: A Theory of Image Restoration. Albany: State University of New York Press.

Benson, J. A., (1998). Crisis revisited: An analysis of the strategies used by Tylenol in the second tampering episode. Central States Speech Journal, 38, 49-66.

Coombs, W. T., (1995). Choosing the right words: The development of guidelines for the selection of the "appropriate" crisis response strategies. Management Communication Quarterly, 8, 447-476.

--------------., (1998). An analytic framework for crisis situation: Better response from a better understanding of the situation. Jurnal of Public Relation Research, 11, 125-142.

--------., (1999a). Information and compassion in crisis response: A test of their effects. Journal of Public Relations Research, 11, 125-142.

------------., (1999b). Ongoing Crisis Communication in Crisis Communicationa: Planning, Managing, and Responding. Thousand Oaks, CA: Sage.

Coombs, W. T., \& Holladays, S. J., (1996). Communication and attribution in a crisis: An experimental study of crisis communication. Journal of Public Relation Research, 8, 279-295.

--,(2001). An extended eximination of the crisis situasion: A fusion of the relational management and symbolic approaches. Journal of Public Relations Researchs, 13, 321-340.

-,( (in press). Matching crisis response strategies to crisis situations: An attribution theorybased approach to crisis management. In D. P. Millar \& R. Heath (Eds.), Crisis Communication: Theory and Applications. Mahwah., NJ: Lawrence Erlbaum.

Cooms, W. T. \& Schmidt, L. (2000). An empirical analysisi of image restoration: Texaco's racism crisis. Journal of Public Relations Research, 12, 163-178.

Fearn-Banks, K. (1996). Ten Guidelines for Redusing Legal Risk in Crisis Management. Public Relations Quarterly, 40(2), 33-38. 
Formburn, C. J. (1996). Reputation: Realizing value from the corporate image. Boston: Harvard Business School Press.

Griffin, M., Babin, B. J., \& Darden, W. R.. (1992). Consumer assessments of responsibility for product-related injuries: The impact of regulation, warnings, and promotional policies. Advances in Consumer Research, 19, 870-877.

Grunig, J. E., \& Hunt, T. (1984). Managing Public Relations. New York: Holt, Reinhart and Winston.

Grunig, J. E., \& Hon, L. (1998). Reconstruction of a situational theory of communication: Internal and external concepts as identifiers of publics for AIDS. Paperpresentes to the Association for Education Journalisme and Mass Communication, Portland, OR.

Grunig, J. E. (1997). A situasional theory of publicr: Conseptual history, recent challenges and newreaearch. In D. Moss, . MacManus, \& D. Vercic (Eds), Public relations research: An international perspective (pp.3-48). London: Internationak Thomson Business Press.

Hearit, K. M. (1996, Fall). The use of counter-attack in apologetic public relations crises: The case of General Motors vs. Dateline NBC. Public Relations Reviews, 22(3), 233-248.

Heath, R. L. (1994). Management of corporate management communication: From interpesonal contacts to external affairs. Hillsdale, NJ: Lawrence Erlbaum.

McAuley, E., Duncan, T. E., \& Russell, D. W. (1992). Measuring causal attributions: The revised Causal Dimension Scale (CDII). Personality and Social Psychology Bulletin, 18, 566-573.

McCroskey, J. C. (1996). An introduction to rhetorical communication. Eaglewood Chliffs, NJ: prentice Hall.

McLauglin, M. L., Cody, M. J., \& O’Hair, H. D. (1983). The management of failure events: Some contextual determinants of accounting behaviour. Human Communication Research, 9, 208-224.

Mittroff, I., I. (1988, Winter). Crisis management: Cutting through yhe confusion. Sloan Management Reviews, 29, 15-20.

Mitroff, I., I., Harrington, K., \& Gai., E. (1996, September). Thinking about the untingkable. Across the Board, 33(8), 4448.

Pauchant, T., C., \& Mitroff, I., I. (1992). Transforming the crisis-prone organization: Preventing individual, organizational, and enviromental tragedies. San Francisco: Jossey-Bass.

Sellnow, T. L., Ulmer, R. R., \& Snider, M. (1998). The compability of corrective action in organizational crisis communication. Communication Quarterly, 46, 60-74.

Struges, D. L. (1994). Communicating through crisis: A strategic for organizational survival. Management Communication Quarterly, 7, 297-316.

Tyler, L. (1997). Liability means never being able to say you're sorry: Corporate guilt, legal constrains, and defensiveness in corporate communication. Management Communication Quarterly, 11, 51-73.

Winkleman, S. (1999, April). The right stuff. Chief Executive, 143, 80-81. 